\section{A CASE OF HEALTH}

BY

RICHARD ASHER, M.D., F.R.C.P.

Physician, Central Middlesex Hospital, London

Many cases of unusual illness are described in these columns, so it may make a change if I report a case of unusual health. The lady I describe here is healthy not only in the sense of never being ill but in the more practical fashion of being useful and hard at work for 76 consecutive years with only 10 days' illness. My knowledge of her is purely social ; she never consults doctors: "I don't believe in them," she says.

Fanny, as everyone calls her, was aged 90 on January 31 and works as a cook and general servant at a girls' dayschool in London. She was born on January 31,1868 . She went to school till the age of 13 , and then started work in domestic service. Since then she has worked at this profession without any illness or absence from work except for 10 days off in 1932 with bronchitis and severe fatigue after she had been nursing her husband with a fatal illness.

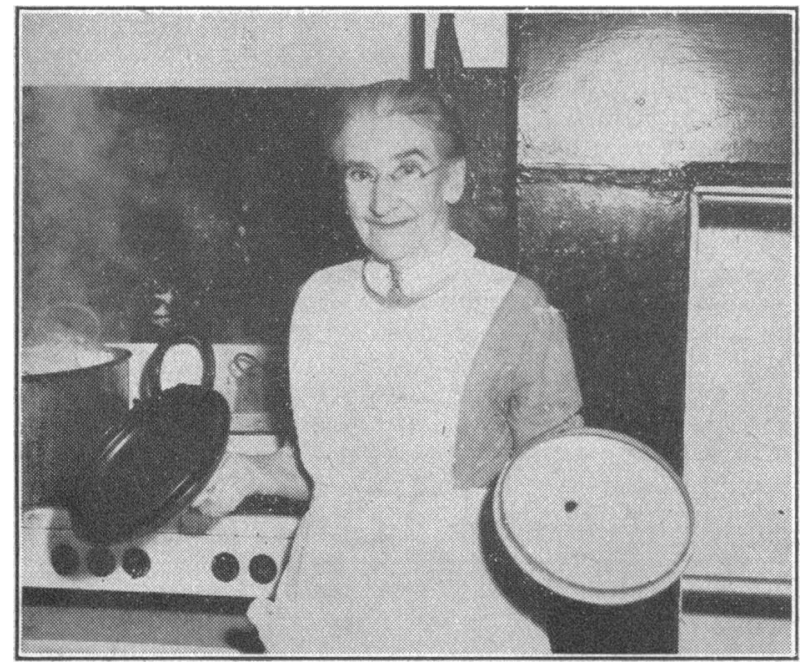

Fanny at her oven, cooking the puddings.

She started her present post 42 years ago; it is both strenuous and responsible. She cooks for 90 people and is also housekeeper to the headmistress. Her average working day is as follows : 6.30 a.m., gets up and takes her dog for a walk, after which she cooks breakfast for four. 9.30 a.m., goes out shopping for the school. 11 a.m., starts cooking the school lunch ready for 1 o'clock. 1.30 p.m., receives and sorts the dirty crockery brought down by the children, takes her dog for a walk, and then changes into a black dress and apron for the afternoon. From 2 to 4 p.m. she is on duty for the front-door bell, but manages to get a little rest during this time. 4 p.m., gets tea ready for the staff of seven teachers. 4.30 p.m., clears up tea. 7 p.m., prepares supper for her mistress. 9.30 to 10 p.m., takes her dog out for an evening walk and then goes to bed.

On Saturdays she does cleaning and polishing. On Sundays she does her washing in the morning and then cooks and serves lunch. She takes the afternoon off and prepares a cold supper for the evening. She stays at the school during the holidays even when her mistress is away, when she is quite alone in the house. She is an alert, spry little woman who moves quickly and vigorously. She enjoys her work, and her mistress, who is devoted to her, regards her as a treasure.

Though many people are very active at 90 , it is rather unusual to perform quite so much responsible work at this age and to work at one job so many years without absence through illness. This rare condition of health is probably hereditary-her mother lived to 100 , her sisters died at 89 and 86 , and her brother is 86 .

\section{ORDER OF ST. JOHN OF JERUSALEM}

Those recently appointed to, or promoted in, the Venerable Order of the Hospital of St. John of Jerusalem include the following members of the medical profession:

As Knights: Drs. J. T. Whitley and R. V. S. Cooper, As Commanders (Brothers): Sir Charles Dodds, F.R.S., Air ViceMarshal L. M. Corbet, Messrs. D. P. Mclntyre and D. W. Montgomery, and Drs. J. C. R. Buchanan, C. H. Drake, M. Y. Paget, G. Swapp, and H. H. Hurst. As Officers (Brothers): Squadron Leader P. Cauthery, Mr. S. W. Cooper, and Drs. H. D. Teare, Chia Boon Leong, W. Duncan, C. T. Newnham, A. Morrison, A. Chalmers, C. F. Fairlie, T.D., A. G. Walker, R. G. Sprenger, R. H. Kipping, R. H. Scott, J. H. C. Clarke, G. N. M. Wishart, F. P. Wallis, S. G. Nelson, J. M. Pedler, N. G. Hoddle, and M. F. Leslie. As Associate Officer (Brother): Dr. N. Pines. As Officer (Sister): Dr. Florence E. Stewart. As Serving Brothers: Major K. C. Greenwood, The Reverend R. H. Smallwood (Assistant-Chaplain), and Drs. J. F. J. Kelly, F. N. Grannum, A. C. Kirton, H. W. Morck, E. M. Sharples, W. B. R. Jones, W. Nixon, Wong Wa Kwan, Lam Yu Shing, Woo Pak Foo, Lam Chiu Chun, W. A. R. Mailer, E. W. Tapley, R. F. Mackenzie, R. W. Rutter, W. H. Mylechreest, D. D. Towle, J. A. Wilson, T. S. McKean, K. E. Inman, J. T. Cullen, A. W. Burton, J. D. Fotheringham, F. L. Thyer, and W. J. Nicholl. As Associate Serving Brothers: Drs. I. S. Patel, S. Lurie, and H. M. Khas. As Serving Sisters: Drs. Kathleen E. Thompson and Annie D. Gibson.

\section{Reports of Societies}

\section{OBSTRUCTION OF THE SMALL INTESTINE}

[From a SPECIAL CoRrespondent]

On February 5 the Surgical Section of the Royal Society of Medicine discussed "Small-bowel Obstruction." Mr. A. Dickson Wright, the Section President, was in the chair.

\section{Acute Obstruction}

Mr. R. V. Cooke, the opening speaker, dealing with acute obstruction, began by quoting the Registrar-General's mortality figures. The death rate for acute obstruction had dropped from 4,000 per annum in the decade before the second world war to just under 3,000 at the present time. This was no very dramatic improvement, and part of it might be accounted for by improved anaesthesia, intravenous infusion, and the services of the chemical pathologist. Obstruction of the small intestine was a treacherous condition. The average general practitioner saw only two cases a year, yet it was vital that he should make the diagnosis early and send these patients to hospital forthwith. A fatal issue might follow the delay when the initial signs were missed or the case was thought to be "only an early one." Delay was the great killer in this disease, whether in the home or in hospital. Mr. Cooke expressed his "violent antipathy" to three common causes of delay in hospital. Some thought, he said, that they could differentiate accurately between simple obstruction and strangulation; this attitude could result in unjustifiably conservative treatment with tragic consequences. Mr. Cooke thought it impossible to distinguish between these two types of obstruction, and he described some alarming cases to illustrate this point. Another cause of delay was the use of the MillerAbbott tube ; a great deal of time might be needed to introduce it into the small bowel, and even if the mancuvre was successful the tube's value in acute obstruction was very limited. A third cause of delay was the policy of "suck and drip to death": pre-operative transfusion should be rapid and aimed at getting the patient into a state suitable for operation at the earliest possible opportunity.

Mr. Cooke then analysed replies from registrars throughout the country to a letter written asking a number of questions on acute obstruction. Nearly all agreed with him that it was impossible to make a certain diagnosis between simple and strangulating obstruction, and some thought it useless and dangerous to try to do so. In patients who were 